\title{
THE IMPACT OF SCHOOL ENVIRONMENT ON TEACHERS' JOB SATISFACTION IN SECONDARY SCHOOLS
}

\author{
Marinette Bahtilla ${ }^{1 i}$, \\ $\mathrm{Xu} \mathrm{Hui}{ }^{2}$ \\ ${ }^{1}$ Faculty of Education, \\ Southwest University, \\ Chongqing, China \\ orcid.org/0000-0003-0965-2251 \\ ${ }^{2}$ Faculty of Education, \\ Southwest University, \\ Chongqing, China
}

\section{Abstract:}

This quantitative correlational study examined the relationship between the school environment and teachers' job satisfaction. The study focused on finding the extent to which four predictors of the school environment (teachers' collaboration, motivation, instructional materials, and teachers' participation in decision making) predict teachers' job satisfaction. Besides, the study also aimed at determining which variable is the best predictor of teachers' job satisfaction. This study was guided by the following research questions: (1) To what extent does teachers' collaboration influence their job satisfaction? (2) To what extent does teachers' participation in decision-making influences their job satisfaction? (3) To what extent does motivation influence teachers' job satisfaction? (4) To what extent do instructional materials influence teachers' job satisfaction? The simple random sampling technique was used for this study. The sample population was made up of all 550 teachers in 15 public secondary schools, 320 females and 230 males. A questionnaire was used as an instrument for data collection. The instrument's validity and reliability were ensured. Descriptive and inferential statistics were used for data analysis. Pearson product-moment correlation was used to determine the relationships between the independent variables and the dependent variable. Simple linear regression was used to determine the amount of variance in the dependent variable accounted for by each independent variable. In addition, a multiple regression was used to assess the ability of four control measures to predict teachers' job satisfaction and to find out which of the independent variables is the best predictor of teachers' job satisfaction. The study found out that all the independent variables make a unique and statistically significant contribution to predicting teachers' job satisfaction. The model explains $84.9 \%$ of the

${ }^{i}$ Correspondence: email barinette@yahoo.com 
variance in teachers' job satisfaction. Teachers' participation in decision-making made the largest contribution (Beta $=.626$ ). This reveals that teachers' participation in decisionmaking is the best predictor of teachers' job satisfaction, followed by motivation (Beta= .532). This study provides useful findings which have implications for school leaders and policy-makers.

Keywords: school environment, teachers' job satisfaction, teachers' participation in decision-making, motivation, teachers' collaboration, instructional materials.

\section{Introduction}

There is a need for every worker in any institution or organization to derive satisfaction in what they are doing. Job satisfaction determines the workers' efficiency, hence the institution's output or the organization (Markos \& Sridevi, 2010; Reeves et al., 2017). Satisfied workers devote their time and energy to the success of the organization. There is a need to ensure that every worker is satisfied. Today, teachers are leaving the teaching profession to other professions, and this may be due to a lack of job satisfaction, which is greatly affecting the quality of education (Ronfeldt et al., 2013; Simon \& Johnson, 2015; Reeves et al., 2017; Bahtilla; 2017; Torres, 2018). Teachers' dissatisfaction can result in a lack of interest in teaching, leading to non-coverage of the syllabus, high failure rate, school drop-out, delinquency, and deviant behavior in schools. Every nation's ability to solve society's social and economic problems depends on what kind of knowledge and skills are taught in schools. School environmental factors are critical; they can either lead to job satisfaction or job dissatisfaction. The school environment can positively or negatively impact employee motivation (Gagné \& Deci, 2005; Fernet et al., 2012).

Every school needs to provide the necessary facilities and the support teachers need in preparing students for the changing and challenging world (Gemeda \& Tynjala, 2015; Djonko-Moore, 2015). A positive school environment nurtures teachers to succeed in teaching and to reach their potentials. The governments of many African countries have been creating more and more teacher training colleges to meet up the demand for teachers' and every year, teacher training colleges graduate thousands of teachers. However, the rate of teachers' shortages is still alarming because most teachers are not satisfied with the teaching profession; they leave when they see a better opportunity (Dupriez et al., 2016; Bahtilla, 2017). This reveals a need for academics to focus on findings strategies to improve teachers' job satisfaction.

\section{Statement of the Problem}

Teachers' job satisfaction is vital to ensure quality education. Satisfied teachers are more likely to devote their time and energy to teaching, hence, improving students' performance (Skaalvik, \& Skaalvik, 2017; Reeves et al., 2017). Schools need to ensure that teachers are satisfied because teachers are the most valuable school improvement assets. There is a need to pay attention to teachers' job satisfaction because it determines 
teachers' commitment and teaching practices, ultimately impacting students' academic performance (Pogodzinski, 2015). Teachers who are not satisfied with their jobs are more likely to feel reluctant to prepare lessons and may not adequately implement the curriculum. This reveals that there is a need for a school environment that ensures teachers' job satisfaction. School environments characterized by adequate instructional materials, motivational strategies, participatory decision-making style, and schools that promote teachers' collaboration can enhance teachers' job satisfaction. In most countries, an unconducive school environment has led to teachers' job satisfaction (Simon \& Johnson, 2015).

If teachers are not satisfied with their job, it may lead to failure to effectively implement the curriculum or even attrition. The retention of qualified and experienced teachers has become a major challenge for most school administrators today. Thus, it is necessary to examine school environmental factors that may influence teachers' job satisfaction so that the education sector can implement appropriate strategies that can stimulate teachers' job satisfaction.

This study was guided by the following research questions:

1) To what extent does teachers' collaboration influence their job satisfaction?

2) To what extent does teachers' participation in decision-making influences their job satisfaction?

3) To what extent does motivation influence teachers' job satisfaction?

4) To what extent do instructional materials influence teachers' job satisfaction?

\section{Literature Review}

\subsection{Conceptual Review}

\subsubsection{School Environment}

Teacher shortages in most schools are determined by the school environment (Ingersoll \& Smith, 2003). Teachers who teach in a positive school environment are more likely to stay in the teaching profession (Ladd, 2011; Tickle et al., 2011; Urick, 2016). However, as a result of the poor working environment, teachers' job dissatisfaction keeps rising. An unconducive school environment can lead to teachers' absenteeism and poor classroom practices, and early departure from the teaching profession. Increased workload and emotional exhaustion lead to job dissatisfaction (Skaalvik \& Skaalvik, 2017). A stressful working environment can lead to teachers' dissatisfaction and, consequently, teacher attrition (Collie et al., 2012; Fernet et al., 2012; Boyd et al., 2011, Bahtilla, 2017). Most schools lack a supportive environment for teaching and learning (Borman \& Dowling, 2008; Simon \& Johnson, 2015). As an instructional leader, the principal needs to ensure that the school environment is conducive to teaching and learning (Bahtilla \& Hui, 2020). Principals who create a friendly and supportive school environment suppress fear in both students and teachers, fostering teaching and learning (Hallinger, 2003; Baptiste, 2019).

A school environment that is comfortable and relatively low in physical and psychological stress can lead to high levels of satisfaction among teachers. According to Fernet et al. (2012), the main cause of burnout is deleterious working conditions. 
Teachers' working conditions are below expectation compared with their counterparts in different occupations (Ladd, 2011; Mafora, 2013). The school environment plays a pertinent role in determining the supply of qualified and experienced teachers and influencing their decisions about remaining in the profession. Schools that are characterized by a safe and supportive environment can enhance teachers' job satisfaction. The school environment determines the quality of knowledge and skills acquired by students (Forte \& Flores, 2014; Simon \& Johnson, 2015). Schools that involve teachers in decision-making create opportunities for teachers' collaboration, provide adequate instructional materials, and implement effective motivational strategies to enhance teachers' job satisfaction, improving students' performance.

\subsubsection{Teachers' Collaboration}

Teachers' collaboration refers to the act of teachers working together in groups or teams to improve educational processes and outcomes (Duyar et al., 2013). Teachers' collaboration can also be defined as a practice where teachers cooperate or work in teams to ensure the effective implementation of the curriculum. Teachers' collaboration can lead to teachers' job satisfaction, commitment, and improvement in students' academic achievement (Duyar et al., 2013; Ronfeldt et al., 2015). Teachers' disunity can lead to dissatisfaction. There is a need for schools to create an environment where teachers can share ideas and help one other to grow professionally. Teacher collaboration enhances professional teacher learning (Jong et al., 2019). Teacher collaboration in planning lessons can improve students' academic achievement (Reeves et al., 2017). Teachers working in teams enjoy shared responsibility and job satisfaction (Krammer et al., 2018). Teachers are likely to feel comfortable in schools that promote collaboration because their social needs are met. According to Maslow's hierarchy of needs theory, teachers need love and affection just like other human beings. Teachers are more likely to feel satisfied with schools that promote collaboration. Positive relationships between teachers make them feel less frustrated (Urick, 2016). Exchanging ideas with other teachers and principals increases the teachers' satisfaction rate because it makes them know that their opinions are pertinent to the school's success and are under full consideration by other teachers and administrators. Furthermore, collaboration reduced the workload of individual teachers' as they work together in planning, implementing, assessing, and evaluating. This is very important as a heavy workload can lead to teachers' job dissatisfaction.

Principals as instructional leaders need to encourage and motivate teachers to engage in collaborative activities that facilitate teaching and learning (Goddard et al., 2015). Teachers often complain that they often feel isolated from colleagues and support systems, leading to dissatisfaction (Tatar, \& Horenczyk, 2003; Urick, 2016). Collaboration can reduce feelings of isolation because through collaboration, teachers feel free and comfortable communicating with one other, leading to job satisfaction and high performance (Johnson et al., 2012; Vangrieken et al., 2015). Teachers search for school environments that can allow them to reach their peak performance level. A lack of a supportive school environment lowers teachers' self-esteem and frustrates them because there is no one to run to when there is a problem. Teachers who teach in schools that 
promote collaboration are more likely to be satisfied with the teaching profession because they feel valued and supported (Ingersoll \&Smith, 2003; Johnson et al., 2012; Forte \& Flores, 2014).

It is necessary for teachers to assist one another; working together in groups or teams enhances growth and development. Effective collaboration can lead to teachers' job satisfaction. Well-planned collaborative activities can enhance teachers' self-efficacy (Darling-Hammond, 2003; Ponjuan et al., 2011). A school environment characterized by an open climate promotes cooperation and respect among staff (Mbua, 2003; Boyd et al., 2011). The school environment determines teachers' willingness to stay in a particular school. Teachers who perceive their school environment as a great place to work are more likely to be satisfied with the teaching profession.

\subsubsection{Teachers' Participation in Decision Making}

Teachers are leaving the teaching profession because of job dissatisfaction associated with a lack of teachers' influence over decision making (Ingersoll, 2001; Boyd et al., 2011). Teachers are often left behind when it comes to decision-making. There is a need for teachers to be involved in decisions that concerns them. Teachers feel appreciated and empowered when school leaders involved them in decision-making. Giving teachers the chance to make school decisions can enhance teachers' job satisfaction (Jackson, 2013; Katz \& Shahar, 2015; Torres, 2018). Teachers who feel valued and respected by other teachers and school leaders are more likely to be satisfied (Sergent, 2003; Dou et al., 2017). Excluding teachers from decision-making may give them the feeling that they are not part of the school, leading to dissatisfaction. The school environment can either give teachers the freedom to make certain decisions about their job or give directives (Ryan \& Deci, 2000). Giving directives can lead to job dissatisfaction. A supportive school environment minimizes stress, provides immediate and valuable feedback, and takes teachers' feelings and opinions into consideration (Sadri \& Bowen, 2011; Fernet et al., 2012). Most school administrators think that if teachers will favor themselves when allowed to participate in decision making rather than the overall growth of the school (Bahtilla, 2017). Principals with this type of perception tend to exclude teachers from participating in school decisions, making teachers feel isolated and less valued. When this happens, teachers feel dissatisfied. Principals need to have complete confidence and trust in teachers to participate in decision-making that directly relates to them. Principals need to be transparent, promote positive school climates and provide teachers with professional development opportunities (Urick, 2016).

A democratic leader allows everyone to vote on an issue before a decision is taken. This type of leadership empowers everyone and promotes collaboration. It is necessary for principals to communicate the vision and mission of schools with every stakeholder involved to ensure effective curriculum implementation (Hallinger et al., 2017; Campbell, 2018; Baptiste, 2019). The leadership of a school can lead to teachers' job satisfaction. Administrative support is vital; teachers are satisfied with school leaders that ensure equality and reward performance. Teachers sometimes complain that school administrators' do not treat them like professionals; some school leaders disrespect 
teachers and made them feel powerless (Bahtilla, 2017). Involving teachers in decisionmaking can enhance their job satisfaction. Administrators have a greater deal of influence over school climate and teacher efficiency. School leaders need to create more democratic environments and stop commanding teachers like children. No teacher will be satisfied when the principal gives commands without taking their needs and wants into consideration. Effective principals consider both the teachers' needs and the organization's objectives (Mbua, 2003). There is a need for shared leadership to give teachers' a sense of empowerment (Minarik et al., 2003).

\subsubsection{Motivation (Extrinsic and Intrinsic)}

Motivation refers to anything that energizes behavior. Many teachers are dissatisfied with the teaching profession due to a lack of motivation. Extrinsic and intrinsic motivation is vital to ensure teachers' job satisfaction. school principals need to develop strategies to motivate teachers. Teachers need to be motivated to improve the quality of education (Rooney, 2015). Teachers' motivation can improve students' academic performance; motivated teachers are likely to provide supportive learning (Kaplan, 2014; Katz \& Shahar, 2015). School leaders must identify and re-enforce teachers based on their individual needs. Recognition of teachers' efforts can lead to commitment in achieving the school objectives and job satisfaction. Motivation can be done in the form of incentives or appraisals (Taniguchi \& Fujii, 2016). Appraisal and professional development can help to retain teachers.

The alarming rate of attrition is caused by teachers' dissatisfaction with their working conditions. This has greatly affected students' academic performance. Teachers need to be motivated to equipped students with sustainable knowledge and skills. Motivated teachers are more likely to take time and plan their lessons to provide students with meaningful learning experiences to solve society's complex problems. Demotivated teachers may not be effective, which is detrimental to the education sector and society's development (Ronfeldt et al., 2013; Dupriez et al., 2016). Teachers who join the teaching profession because they thought their needs could be met are more likely to look for other opportunities if their needs are not met. School leaders are expected to give genuine and frequent praise. As instructional leaders, principals are also expected to respect the professional competence of staff when giving feedback. The manner and nature in which feedback is given can either motivate or demotivate teachers. According to Herzberg et al. (1959), factors such as recognition, achievement, responsibility, advancement, the meaningfulness of the work yield positive satisfaction. The presence of these satisfiers in the school environment makes teachers feel good about their job.

\subsubsection{Instructional Materials}

Instructional materials can be defined as learning and teaching tools that supplement what the textbook provides (Abdu-Raheem, \& Oluwagbohunmi, 2015). Ikerionwu (2000) defines instructional materials as objects or devices that assist teachers in presenting lessons to the learners logically. In this study, instructional materials refer to teaching aids, which can help teachers explain or demonstrate a phenomenon to enhance students' 
understanding. Instructional materials vary from subject to subject; they could be charts, tape recorders, computers, magazines, newspapers, pictures, just to name. However, these instructional materials do not only enhance teachers' satisfaction, but they also make learning more practical, thereby enhancing students' retention. Olayinka (2016), in an experimental study, found out that students who were taught using instructional materials perform better than those who were taught without instructional materials.

Instructional materials motivate and help students pay attention in class, which means that they can enhance students' academic performance. In most developing countries, classrooms are so bare of instructional materials, increasing the level of teacher dissatisfaction and stress (Abdu-Raheem, \& Oluwagbohunmi, 2015). Instructional materials in most developing countries are limited to textbooks and chalkboards (Mupa \& Chinooneka, 2015). It is pretty difficult for teachers to explain complex concepts without instructional materials. Most students find it challenging to comprehend what is being taught in class due to a lack of instructional materials. Many secondary schools in Cameroon have an unconducive school environment; most schools do not have basic requirements for successful teaching and learning, leading to dissatisfaction (Bahtilla, 2017). In the United States of American, 20\% of teachers leave high-poverty schools every year (Djonko-Moore, 2015). This is because, in high poverty, schools cannot provide the basic facilities teachers need to facilitate teaching. According to the New Alliance Report (2014), over half a million United States teachers either move or leave the profession each year and most of these teachers are from schools with little resources hence, affecting the quality of education. The school environment has an essential part to play as far as teachers' job is concerned. Inadequate instructional materials can influence teachers' satisfaction

Lack of instructional materials makes learning very abstract. Adequate instructional materials can improve teacher effectiveness, enhance their commitment to school, and promote job satisfaction. Lack of resources can negatively impact employees' motivation, reducing their performance (Bakker et al., 2003). In most developing countries, teachers often used their money to buy instructional materials. Instructional leaders need to ensure that teachers have adequate tools and resources required for effective curriculum implementation. Inadequate instructional materials may not only affect teaching practices, but it might also cause teachers to leave the teaching profession to other professions (Bahtilla, 2017). Lack of instructional materials is one of the challenges affecting teachers in developing countries (Ndongko \& Tambo 2000). Inadequate instructional materials made teaching and learning stressful and tedious, which can lead to teachers' dissatisfaction. It is vital for principals as instructional leaders to ensure that instructional materials are of good quality, and they are suitable for a particular lesson and that the teachers are using them appropriately (Alabere, 2017; Bahtilla \& Hui, 2020)

\subsubsection{Teachers' Job Satisfaction}

Job satisfaction refers to an employee's feelings about their gains and successes in the work environment (Aziri, 2011). Job satisfaction can also be defined as the fulfillment 
level gained from work (Torres, 2018). Job satisfaction in this study refers to the extent to which teachers' hopes, desires, and expectations about the teaching profession are fulfilled. In any organization, people who are dissatisfied with their jobs often quit and pursue other careers (McShane \& Glinow, 2003; Dupriez et al., 2016). Job dissatisfaction has led to teachers' attrition (Tambo, 2003; Ingersoll, 2003). Teachers who are satisfied with their jobs are happy, which often reflects their interactions with other teachers and students' satisfaction (Tillman \& Tillman, 2008; Ronfeldt et al., 2013). Satisfied teachers are more likely to remain in the teaching profession, come to class regularly, while dissatisfied teachers are more likely to miss classes and look for other job opportunities. Teachers' who are satisfied with their jobs show a higher level of commitment than those who are dissatisfied. Satisfied teachers can work extra hours to ensure that students acquire sustainable skills. This means that it is vital to ensure teachers' job satisfaction. Teachers' job satisfaction can influence their efficiency and productivity (Rooney, 2015). A satisfied teacher encourages and motivates students, leading to improved performance (Chireshe \& Shumba, 2011; Skaalvik \& Skaalvik, 2017). On the other hand, teachers who are not satisfied with their careers can have a negative impact on students' learning and the overall performance of the schools. It is important to note that teachers' job satisfaction greatly influences their performance, which tends to influence students' academic performance.

There is a need for teachers' needs and goals to align with school goals (Zhilla, 2013). When teachers' goals align with the school goals, they will devote their time and energy to achieve them. Moreover, it brings the feeling of belongingness which leads to satisfaction. Teachers are more likely to remain satisfied with their jobs if there is good leadership and a positive school climate. To a greater extent school environment need to be satisfactory. When teachers' basic needs cannot be met, job satisfaction may be impossible (Waltman et al., 2012). Most schools, especially in developing countries, are characterized by limited resources, diverse learners, and students' indiscipline, making the teaching profession challenging and stressful. A stressful teacher may not effectively implement the curriculum, consequently affecting education quality (Embse et al., 2016; Skaalvik \& Skaalvik, 2017). Most teachers find it challenging to cope with classroom management practices and the high demands from school leaders and even parents, leading to job dissatisfaction (Grissom et al., 2014). All of this has made the teaching profession more stressful than other occupations (Stoeber \& Rennert, 2008). Nobody wants a job that is likely to bring depression and anxiety. The education sector has been experiencing relatively high attrition rates than other professions such as engineering and law (Ingersoll \& Smith, 2011). This reveals that there is a need to examine school factors that can be re-enforced or implemented to enhance teachers' job satisfaction.

\subsection{Theoretical Review}

This study was guided by Herzberg's Two-Factor Theory of motivation. 


\subsubsection{Herzberg's Two-Factor Theory of Motivation (Herzberg, Mausner \& Snyderman,} 1959)

Herzberg and his colleagues found out that workers tend to describe satisfying experiences in terms of intrinsic factors relating to the work itself and dissatisfaction experiences in extrinsic factors relating to the working environment. Based on the findings, they proposed a two-factor theory or the motivation-hygiene theory. Some job factors result in satisfaction, while other job factors prevent dissatisfaction. According to Herzberg et al. (1959), some job factors result in satisfaction, while other job factors prevent dissatisfaction. He classified these job factors into two categories:

\subsubsection{Hygiene Factors and Motivational Factors}

Hygiene factors are those factors that do not lead to positive satisfaction for a long time, but if these factors are absent, they lead to dissatisfaction. Therefore, hygiene factors are essential as they help to avoid dissatisfaction. The two-factor theory may help secondary schools leaders to focus on enriching the school environment. However, school leaders need to note that hygiene factors alone cannot sustain satisfaction (Gemeda \& Tynjala, 2015). Workers seek satisfaction by achieving hygiene needs, for example, relationships on the job, working conditions, instructional materials (Roby, 2012). Creating opportunities for teachers to come together is also essential; principals can organize regular social programs where teachers can interact and feel more involved in school activities; for example, school leaders can promote the spirit of togetherness amongst staff members during these programs. An environment where teachers can feel free and enjoy each other's warmness and love without any form of indifference is essential. However, hygiene needs are not long-lasting, so workers need motivators, such as professional development, personal growth, recognition, achievement, advancement, responsibility, and the work itself (Chandra et al., 2011). In most schools, teachers are dissatisfied because a majority of Herzberg's dissatisfies are commonly found in the school environment (Bahtilla, 2017). Therefore, school leaders need to provide hygiene factors to reduce teachers' dissatisfaction and be sure to include motivators because they are the factors that can sustain teachers' job satisfaction, leading to the effective implementation of the curriculum.

According to Herzberg, motivational factors are called satisfiers. Motivational factors can lead to satisfaction which can enhance teachers' performance. Satisfiers are the key motivators to improving work performance. Employees find these factors intrinsically rewarding. As a motivational factor, school leaders can involve teachers in decision making. This can enhance teachers' engagement in school activities leading to job satisfaction. Active participation of teachers in school activities can promote greater commitment and lower emotional stress (Taniguchi \& Fujii, 2016; Urick, 2016; Krammer et al., 2018). The school activities should be made as interesting as possible since the basic assumption of Herzberg's theory is that the job or the activity itself is a powerful intrinsic motivator. When employees are motivated, they tend to be more satisfied and committed (Khumalo, 2015; Ali et al., 2016). School leaders need to recognize teachers' efforts and appreciate their achievements (Dou et al., 2017). 


\section{The hypothesis of the Study}

Ho1: There is no significant relationship between teachers' collaboration and their job satisfaction (Ho: $\mu=0$ )

Ha1: There is a significant relationship between teachers' collaboration and their job satisfaction (Ha: $\mu \neq 0$ )

Ho2: There is no significant relationship between teachers' participation in decision making and their job satisfaction (Ho: $\mu=0$ )

Haz: There is a significant relationship between teachers' participation in decision making and their job satisfaction (Ha: $\mu \neq 0$ )

Ноз: There is no significant relationship between motivation and teachers' job satisfaction $(\mathrm{H} 0: \mu=0)$

Наз: There is a significant relationship between motivation and teachers' job satisfaction (Ha: $\mu \neq 0$ )

$\mathbf{H}_{\text {o4: }}$ There is no significant relationship between instructional materials and teachers' job satisfaction $\left(\mathrm{H}_{0}: \mu=0\right)$

Ha: There is a significant relationship between instructional materials and teachers' job satisfaction (Ha: $\mu \neq 0$ )

\section{Research Method}

The quantitative correlational design was used for this study. According to Creswell (2012), the correlational design is used when the researcher wants to determine if two or more variables influence each other. This study aimed to examine the relationship between school environment and teachers' job satisfaction, making correlation the best research design to use. Furthermore, the correlational design is the most appropriate for this study because it gives the researcher the chance to predict scores and explain the relationship among variables (Creswell \& Plano, 2011). The correlational prediction design was used. According to Creswell (2012), prediction research is pertinent because it helps to forecast the future.

The study was carried out in the North and Southwest regions of Cameroon. Cameroon is a bilingual country with English and French used as official languages. The country is divided into ten regions, two of which are English speaking and eight are French-speaking. The two English regions were purposefully selected; that is, regions with English as the language of instruction were selected. The Republic of Cameroon is situated in Central Africa; it lies between latitudes $1^{0}$ and $13^{\circ} \mathrm{N}$ of the equator and longitudes $8^{0}$ and $13^{\circ} \mathrm{E}$ of the Greenwich meridian. The country shares boundaries with other African countries; in the North, it shares a boundary with the Republic of Chad, the West by Nigeria, the East by the Central African Republic, and the South by Equatorial Guinea, Gabon, Congo, and the Atlantic Ocean. Cameroon is often referred to as "Africa in miniature" because of its geological and cultural diversity.

The population of the study was made up of secondary teachers in the North and South West Region of Cameroon. The justification for choosing teachers is because they 
are in the best position to give information about teachers' job satisfaction. 15 secondary schools were randomly selected. The sample population was made up of all 550 teachers in 15 public secondary schools. 320 females and 230 males. This sample was chosen proportionately to the total population as recommended by Krejcie and Morgan (1970). The respondents' age ranged from 20 to 62, and their experience as teachers ranged from 1 to 42 years.

A questionnaire was used as an instrument for data collection. The questionnaire focused on the school environment (teachers' collaboration, motivation, instructional materials, teachers' participation in decision-making) and teachers' job satisfaction. The questionnaire was constructed in English, and since all the participants were proficient in the English language, there was no need for translation. The researchers constructed questionnaire items, and the validity and reliability of the instrument were ascertained. 550 questionnaire copies were administered, and 502 were returned. The questionnaire contains closed-ended items with alternative response options in a Likert scale of Strongly Agree (SA), Agree (A), Disagree (D), and Strongly Disagree (SD).

Job satisfaction was measured using six items; some of these items are: (1) I enjoy teaching at this school (2) If given a chance to choose another profession, I will still choose to teach. The Cronbach's alpha for the teachers' job satisfaction scale was 0.90 . Teachers' participation in decision-making was measured using six items; some of these items are; (1) There are opportunities in this school for teachers to actively participate in school decisions. (2) Teachers have the right to make decisions concerning their classrooms. (3)There is shared responsibility in this school. The Cronbach's alpha for teachers' participation in the decision-making scale was 0.87 . The motivation was measured using six items; for example (1) A development plan is established for teachers' growth and development. Cronbach's alpha for the motivation scale was 0. 89. Teachers' collaboration was measured using six items; some of these items include; (1) There is mutual support in this school. (2) Teachers in this collaborate in planning lessons. (3) There are opportunities for teachers to share their teaching experiences with other teachers. Cronbach's alpha for teachers' collaboration scale was 0.79 . The instructional material scale was made up of six items; some of these items are; (1) Instructional materials facilitate teaching. (2) This school assists teachers in providing instructional materials. Cronbach's alpha for the scale of the instructional material was 0.78. These validity indices ascertained that the instrument was valid enough to be used for the study

The instrument's validity and reliability were ensured; to ensure the instrument's face validity, the researcher gave the questionnaire to ten postgraduates and three professors to read through and make some corrections and suggestions on grammar, organization, and parts incomprehensible. The researchers also revised the questionnaire items several times, checking the appropriateness of language, clarity, and suitability. Furthermore, to ensure the instrument's content validity, the researcher checked the questionnaire items' relevance to the study's objectives. This was confirmed by an expert in Educational Measurement and statistics.

Moreover, to ensure reliability, the instrument was trial-tested using 50 respondents who are part of the population but not included in the study sample. The 
data collected was then tested for reliability using the Cronbach Coefficient Alpha method. The reliability estimates ranged from 0.78 to 0.90 . The results confirmed that the instrument was reliable enough to be used for the research.

Five research assistants were employed; the assistants were trained for four days to ensure the instrument's effective administration. The assistants guided the teachers and personally administered the questionnaire to them face to face. Most teachers filled the questionnaire during break time, while some ask for permission to take it home. Descriptive and inferential statistics were used for data analysis. The statistical tools used for analysis were Pearson Product Correlation Moment, simple linear regression, and multiple regression. Pearson product-moment correlation was used to determine the relationships between the independent variables and the dependent variable. Correlation is used when the researcher wishes to measure the degree, association, or relationship between two or more variables or sets of scores (Creswell, 2014).

Simple linear regression was used to determine the amount of variance in the dependent variable accounted for by each independent variable. In addition, a multiple regression was used to assess the ability of four control measures (teachers' collaboration, motivation, instructional materials, and teachers' participation in decision making) to predict teachers' job satisfaction and to find out which of the independent variables is the best predictor of teachers' job satisfaction. It is pertinent to point out that, in every scientific research, it is fundamental to follow ethical guidelines. Ethical issues were addressed in the introductory section of the questionnaire. The researchers state the purpose of the research and assured the respondents about the confidentiality of their responses and the availability of the results to them after analysis. The respondents were informed that by voluntarily participating in this study, they contribute to solving the challenges faced by today's education sector. The researchers obtained permission from the principals of all the schools that were selected for the study. The principals then introduced the researchers to the teachers. Participation was voluntary.

\section{Findings}

It is vital to point out that preliminary analyses were performed to ensure no violation of the assumptions of normality, linearity, and homoscedasticity.

Table 1: Descriptive Statistics

\begin{tabular}{|l|c|c|c|}
\hline & Mean & Std. Deviation & N \\
\hline Teachers' Job Satisfaction & 9.8076 & 1.42769 & 502 \\
\hline Instructional Materials & 8.7423 & 2.19304 & 502 \\
\hline Motivation & 9.7898 & 1.55571 & 502 \\
\hline Participation in Decision Making & 9.4142 & 2.14133 & 502 \\
\hline Teachers' Collaboration & 8.3864 & 2.11589 & 502 \\
\hline
\end{tabular}

\subsection{Teachers' Collaboration and Job Satisfaction}

Table 2 indicates that the correlation $r$ is .562, indicating a moderately strong positive relationship. The correlation between teachers' collaboration and teachers' job 
satisfaction is statistically significant, $\mathrm{r}=.562 \mathrm{n}=502, \mathrm{p}<.001$. Which shows that teachers' collaboration is associated with teachers' job satisfaction? The regression equation for predicting job satisfaction from teachers' collaboration is $\mathrm{Y}=6.63+0.38(\mathrm{x}) \mathrm{r}^{2}$ is $.315(31.5 \%)$, which shows the proportion of variance in teachers' job satisfaction accounted for by teachers' collaboration. $31.5 \%$ of the variance in teachers' job satisfaction is associated with teachers' collaboration. The null hypothesis was rejected.

Table 2: Correlation between Teachers' Job Satisfaction and Teachers' Collaboration

\begin{tabular}{|l|l|c|c|}
\hline \multicolumn{2}{|c|}{} & $\begin{array}{c}\text { Teachers' Job } \\
\text { Satisfaction }\end{array}$ & $\begin{array}{c}\text { Teachers' } \\
\text { Collaboration }\end{array}$ \\
\hline \multirow{4}{*}{$\begin{array}{l}\text { Teachers' } \\
\text { Job }\end{array}$} & Pearson Correlation & 1 & $.562^{* *}$ \\
\cline { 2 - 4 } & Sig. (2-tailed) & & .000 \\
\cline { 2 - 4 } & Sum of Squares and Cross-products & 1021.182 & 849.949 \\
\cline { 2 - 4 } & Covariance & 2.038 & 1.697 \\
\cline { 2 - 4 } & $\mathrm{N}$ & 502 & 502 \\
\hline \multirow{4}{*}{$\begin{array}{l}\text { Teachers' } \\
\text { Collaboration }\end{array}$} & Pearson Correlation & $.562^{* *}$ & 1 \\
\cline { 2 - 4 } & Sig. (2-tailed) & .000 & 2242.968 \\
\cline { 2 - 4 } & Sum of Squares and Cross-products & 849.949 & 4.477 \\
\cline { 2 - 4 } & Covariance & 1.697 & 502 \\
\cline { 2 - 4 } & $\mathrm{N}$ & 502 & \\
\hline
\end{tabular}

**. Correlation is significant at the 0.01 level (2-tailed).

Table 3 presents the coefficients of teachers' collaboration predicting job satisfaction. It indicates that for every one-unit increase in teachers' collaboration, teachers' job satisfaction will increase by .379. Also, the standardized coefficient shows that for everyone standard deviation increases in teachers' collaboration, teachers' job satisfaction will increase by .562 of the standard deviation. This indicates that teachers' collaboration can predict teachers' job satisfaction.

Table 3: Coefficients

\begin{tabular}{|c|c|c|c|c|c|c|c|c|}
\hline \multirow{2}{*}{\multicolumn{2}{|c|}{ Model }} & \multicolumn{2}{|c|}{$\begin{array}{l}\text { Unstandardized } \\
\text { Coefficients }\end{array}$} & \multirow{2}{*}{$\begin{array}{c}\text { Standardized } \\
\text { Coefficients } \\
\text { Beta }\end{array}$} & \multirow[t]{2}{*}{$\mathrm{T}$} & \multirow[t]{2}{*}{ Sig. } & \multicolumn{2}{|c|}{$\begin{array}{l}95.0 \% \text { Confidence } \\
\text { Interval for B }\end{array}$} \\
\hline & & B & Std. Error & & & & $\begin{array}{l}\text { Lower } \\
\text { Bound }\end{array}$ & $\begin{array}{l}\text { Upper } \\
\text { Bound }\end{array}$ \\
\hline \multirow[t]{2}{*}{1} & (Constant) & 6.630 & .216 & & 30.702 & .000 & 6.205 & 7.054 \\
\hline & $\begin{array}{l}\text { Teachers' } \\
\text { Collaboration }\end{array}$ & .379 & .025 & .562 & 15.177 & .000 & .330 & .428 \\
\hline
\end{tabular}

a. Dependent Variable: Teachers' Job satisfaction

\subsection{Teachers' Participation in Decision-making and Job Satisfaction}

Table 4 shows that correlation $\mathrm{r}$ is .693 , which indicates a strong positive relationship. The correlation between teachers' participation in decision-making and teachers' job satisfaction is statistically significant, $r=.693 \mathrm{n}=502, \mathrm{p}<.001$. The regression equation for predicting job satisfaction from teachers' collaboration is $Y=5.46+0.46(x) r^{2}$ is $.480(48 \%)$, which indicates the proportion of variance in teachers' job satisfaction accounted for by teachers' participation in decision making. $48 \%$ of the variance in teachers' job satisfaction 
is associated with teachers' participation in decision-making. The null hypothesis was rejected.

Table 4: The Correlation between Decision Making and Teachers' Job Satisfaction

\begin{tabular}{|c|c|c|c|}
\hline & & $\begin{array}{c}\text { Teachers' Job } \\
\text { Satisfaction }\end{array}$ & $\begin{array}{c}\text { Participation in } \\
\text { Decision Making }\end{array}$ \\
\hline \multirow{5}{*}{$\begin{array}{l}\text { Teachers' } \\
\text { Job } \\
\text { Satisfaction }\end{array}$} & Pearson Correlation & 1 & $.693^{* *}$ \\
\hline & Sig. (2-tailed) & & .000 \\
\hline & Sum of Squares and Cross-products & 1021.182 & 1061.424 \\
\hline & Covariance & 2.038 & 2.119 \\
\hline & $\mathrm{N}$ & 502 & 502 \\
\hline \multirow{5}{*}{$\begin{array}{l}\text { Participation } \\
\text { in Decision } \\
\text { Making }\end{array}$} & Pearson Correlation & $.693^{* *}$ & 1 \\
\hline & Sig. (2-tailed) & .000 & \\
\hline & Sum of Squares and Cross-products & 1061.424 & 2297.222 \\
\hline & Covariance & 2.119 & 4.585 \\
\hline & $\mathrm{N}$ & 502 & 502 \\
\hline
\end{tabular}

**. Correlation is significant at the 0.01 level (2-tailed).

Table 5 presents the coefficients of teachers' participation in decision-making predicting job satisfaction. It indicates that for every one-unit increase in teachers' participation in decision making, teachers' job satisfaction will increase by .462. Besides, the standardized coefficient shows that for everyone standard deviation increases in teachers' participation in decision making, teachers' job satisfaction will increase by .693 of the standard deviation. This shows that teachers' participation in decision-making can predict teachers' job satisfaction.

Table 5: Coefficients

\begin{tabular}{|c|c|c|c|c|c|c|c|c|}
\hline \multirow{2}{*}{\multicolumn{2}{|c|}{ Model }} & \multicolumn{2}{|c|}{$\begin{array}{c}\text { Unstandardized } \\
\text { Coefficients }\end{array}$} & \multirow{2}{*}{$\begin{array}{c}\begin{array}{c}\text { Standardized } \\
\text { Coefficients }\end{array} \\
\text { Beta }\end{array}$} & \multirow[t]{2}{*}{$T$} & \multirow[t]{2}{*}{ Sig. } & \multicolumn{2}{|c|}{$\begin{array}{c}95.0 \% \text { Confidence } \\
\text { Interval for B }\end{array}$} \\
\hline & & $\mathbf{D}$ & & & & & Lower & Upper \\
\hline \multirow[t]{2}{*}{1} & $\begin{array}{l}\text { (Constant) } \\
\text { Participation in }\end{array}$ & 5.458 & .208 & & 26.299 & .000 & 5.050 & 5.865 \\
\hline & $\begin{array}{l}\text { Decision } \\
\text { Making }\end{array}$ & .462 & .021 & .693 & 21.494 & .000 & .420 & .504 \\
\hline
\end{tabular}

a. Dependent Variable: Teachers' Job satisfaction.

\subsection{Motivation and Teachers' Job Satisfaction}

Table 6 shows the correlation $\mathrm{r}$ is .417, which indicates a moderate correlation. The correlation between motivation and teachers job satisfaction was statistically significant, $r=.417 \mathrm{n}=502, \mathrm{p}<.001$. Findings from simple linear regression show that the regression equation for predicting job satisfaction from motivation is $Y=5.98+0.39(x)$. The $\mathrm{r}^{2}$ is .174 $(17.4 \%)$, which shows the proportion of variance in teachers' job satisfaction accounted for by motivation. That is, $17.4 \%$ of the variance in teachers' job satisfaction is associated with motivation. The null hypothesis was rejected. 
Table 6: The Correlation between Motivation and Teachers Job Satisfaction

\begin{tabular}{|l|l|c|c|}
\hline \multicolumn{2}{|c|}{} & $\begin{array}{c}\text { Teachers' } \\
\text { Job satisfaction }\end{array}$ & Motivation \\
\hline \multirow{4}{*}{$\begin{array}{l}\text { Teachers' } \\
\text { Job }\end{array}$} & Patisfaction & 1 & $.417^{* *}$ \\
\cline { 2 - 4 } & Sig. (2-tailed) & & .000 \\
\cline { 2 - 4 } & Sum of Squares and Cross-products & 1061.424 & 472.786 \\
\cline { 2 - 4 } & Covariance & 2.119 & .944 \\
\cline { 2 - 4 } & $\mathrm{N}$ & 502 & 502 \\
\hline \multirow{4}{*}{ Motivation } & Pearson Correlation & $.417^{* *}$ & 1 \\
\cline { 2 - 4 } & Sig. (2-tailed) & .000 & 1212.541 \\
\cline { 2 - 4 } & Sum of Squares and Cross-products & 472.786 & 2.420 \\
\cline { 2 - 4 } & Covariance & .944 & 502 \\
\cline { 2 - 4 } & $\mathrm{N}$ & 502 & \\
\hline
\end{tabular}

**. Correlation is significant at the 0.01 level (2-tailed).

Table 7 presents the coefficients of motivation predicting teachers' job satisfaction. It indicates that for every one-unit increase in motivation, teachers' job satisfaction will increase by .390 . Moreover, the standardized coefficient shows that for every standard deviation increase in motivation, teachers' job satisfaction will increase by .417 . This shows that motivation can predict teachers' job satisfaction.

Table 7: Coefficients

\begin{tabular}{|c|c|c|c|c|c|c|c|c|}
\hline \multirow{2}{*}{\multicolumn{2}{|c|}{ Model }} & \multicolumn{2}{|c|}{$\begin{array}{l}\text { Unstandardized } \\
\text { Coefficients }\end{array}$} & \multirow{2}{*}{$\begin{array}{c}\begin{array}{c}\text { Standardized } \\
\text { Coefficients }\end{array} \\
\text { Beta }\end{array}$} & \multirow[t]{2}{*}{$T$} & \multirow[t]{2}{*}{ Sig. } & \multicolumn{2}{|c|}{$\begin{array}{l}95.0 \% \text { Confidence } \\
\text { Interval for B }\end{array}$} \\
\hline & & B & Std. Error & & & & $\begin{array}{l}\text { Lower } \\
\text { Bound }\end{array}$ & $\begin{array}{l}\text { Upper } \\
\text { Bound }\end{array}$ \\
\hline \multirow[t]{2}{*}{1} & (Constant) & 5.977 & . 377 & & 15.853 & .000 & 5.236 & 6.718 \\
\hline & Motivation & .390 & .038 & .417 & 10.251 & .000 & .315 & .465 \\
\hline
\end{tabular}

a. Dependent Variable: Teachers' Job satisfaction

\subsection{Instructional Materials and Teachers' Job Satisfaction}

Table 8 shows that the correlation $\mathrm{r}$ is .674, which indicates a strong correlation. The correlation between instructional materials and teachers job satisfaction is statistically significant, $\mathrm{r}=.674 \mathrm{n}=502, \mathrm{p}<.001$. Findings from linear regression show that the regression equation for predicting teachers' job satisfaction from instructional materials is $\mathrm{Y}=5.97+0.44(\mathrm{x})$. The $\mathrm{r}^{2}$ is $.455(45.5 \%)$, which shows the proportion of variance in teachers' job satisfaction accounted for by instructional materials. That $45.5 \%$ of the variance in job satisfaction is associated with instructional materials. The null hypothesis was rejected. 
Table 8: The Correlation between Instructional Materials and Teachers Job Satisfaction

\begin{tabular}{|l|l|c|c|}
\hline \multicolumn{2}{|c|}{} & $\begin{array}{c}\text { Teachers' Job } \\
\text { satisfaction }\end{array}$ & $\begin{array}{c}\text { Instructional } \\
\text { Materials }\end{array}$ \\
\hline \multirow{4}{*}{$\begin{array}{l}\text { Teachers' } \\
\text { Job }\end{array}$} & Satisfaction & 1 & $.674^{* *}$ \\
\cline { 2 - 4 } & Sig. (2-tailed) & & .000 \\
\cline { 2 - 4 } & Sum of Squares and Cross-products & 1021.182 & 1057.718 \\
\cline { 2 - 4 } & Covariance & 2.038 & 2.111 \\
\cline { 2 - 4 } & $\mathrm{N}$ & 502 & 502 \\
\hline \multirow{4}{*}{$\begin{array}{l}\text { Instructional } \\
\text { Materials }\end{array}$} & Pearson Correlation & $.674^{* * *}$ & 1 \\
\cline { 2 - 4 } & Sig. (2-tailed) & .000 & 2409.528 \\
\cline { 2 - 4 } & Sum of Squares and Cross-products & 1057.718 & 4.809 \\
\cline { 2 - 4 } & Covariance & 2.111 & 502 \\
\cline { 2 - 4 } & $\mathrm{N}$ & 502 & \\
\hline
\end{tabular}

**. Correlation is significant at the 0.01 level (2-tailed).

Table 9 presents the coefficients of instructional materials predicting teachers' job satisfaction. It shows that for every one-unit increase in instructional materials, teachers' job satisfaction will increase by .439 . Furthermore, the standardized coefficient indicates that for everyone standard deviation increases in instructional materials, teachers' job satisfaction will increase by .674 of the standard deviation.

Table 9: Coefficients

\begin{tabular}{|c|c|c|c|c|c|c|c|c|}
\hline \multirow{2}{*}{\multicolumn{2}{|c|}{ Model }} & \multicolumn{2}{|c|}{$\begin{array}{c}\text { Unstandardized } \\
\text { Coefficients }\end{array}$} & \multirow{2}{*}{$\begin{array}{c}\begin{array}{c}\text { Standardized } \\
\text { Coefficients }\end{array} \\
\text { Beta }\end{array}$} & \multirow[t]{2}{*}{$T$} & \multirow[t]{2}{*}{ Sig. } & \multicolumn{2}{|c|}{$\begin{array}{l}95.0 \% \text { Confidence } \\
\text { Interval for B }\end{array}$} \\
\hline & & $\mathbf{D}$ & C1d $\mathrm{I}_{\mathrm{n}}$ & & & & Lower & Upper \\
\hline \multirow[t]{2}{*}{1} & (Constant) & 5.970 & .194 & & 30.810 & .000 & 5.589 & 6.351 \\
\hline & $\begin{array}{l}\text { Instructional } \\
\text { Materials }\end{array}$ & .439 & .021 & .674 & 20.418 & .000 & .397 & .481 \\
\hline
\end{tabular}

a. Dependent Variable: Teachers' Job Satisfaction

Multiple regression was also conducted to assess four control measures' ability (teachers' collaboration, motivation, instructional materials, and teachers' participation in decision making) to predict teachers' job satisfaction. Preliminary analyses were conducted to ensure no violation of the assumptions of normality, linearity, multi-collinearity, and homoscedasticity. The model explains $84.9 \%$ of the variance in teachers' job satisfaction. This is quite a significant and respectable finding. Table 11 shows that teachers' participation in decision-making made the largest unique contribution (Beta= .626). This reveals that teachers' participation in decision-making is the best predictor of teachers' job satisfaction, followed by motivation (Beta $=.532$ ). 
Table 10: Correlation Coefficients between Study Variables

\begin{tabular}{|l|c|c|c|c|}
\hline Variables & $\mathbf{1}$ & $\mathbf{2}$ & $\mathbf{3}$ & $\mathbf{4}$ \\
\hline 1 Teachers' job satisfaction & - & & & \\
\hline 2 Teachers' collaboration & .562 & - & & \\
\hline 3 Participation in decision-making & .693 & .511 & - & \\
\hline 4. Motivation & .417 & .219 & .220 & - \\
\hline 5. Instructional materials & .674 & .481 & .638 & .264 \\
\hline
\end{tabular}

Note: All correlations were statistically significant at $\mathrm{p}<0.01$.

Table 11: Coefficients

\begin{tabular}{|c|c|c|c|c|c|c|c|c|c|c|}
\hline \multirow{2}{*}{ Model } & \multicolumn{2}{|c|}{$\begin{array}{l}\text { Unstandardized } \\
\text { Coefficients }\end{array}$} & \multirow{2}{*}{$\begin{array}{c}\begin{array}{c}\text { Standardized } \\
\text { Coefficients }\end{array} \\
\text { Beta }\end{array}$} & \multirow[t]{2}{*}{$T$} & \multirow[t]{2}{*}{ Sig. } & \multicolumn{3}{|c|}{ Correlations } & \multicolumn{2}{|c|}{$\begin{array}{c}\text { Collinearity } \\
\text { Statistics }\end{array}$} \\
\hline & B & $\begin{array}{l}\text { Std. } \\
\text { Error }\end{array}$ & & & & $\begin{array}{l}\text { Zero- } \\
\text { order }\end{array}$ & Partial & Part & Tolerance & VIF \\
\hline & & & & & & & & & & \\
\hline $\begin{array}{l}\text { Instructional } \\
\text { Materials }\end{array}$ & .110 & .016 & .168 & 7.013 & .000 & .674 & .300 & .122 & .527 & 1.899 \\
\hline Motivation & .489 & .017 & .532 & 28.541 & .000 & .408 & .788 & .497 & .872 & 1.146 \\
\hline $\begin{array}{l}\text { Participation } \\
\text { in Decision } \\
\text { Making }\end{array}$ & .417 & .017 & .626 & 24.678 & . 000 & .693 & .742 & .430 & .472 & 2.119 \\
\hline $\begin{array}{l}\text { Teachers' } \\
\text { Collaboration }\end{array}$ & .102 & .014 & .151 & 7.194 & .000 & .562 & .307 & .125 & .691 & 1.447 \\
\hline
\end{tabular}

Table 11 shows the tolerance value of each independent variable (an indicator of how much of the variability of each independent is not explained by the other independent variables in the model). No tolerance value is less than .10, which indicates that there is no multi-collinearity. Moreover, the Variance inflation factor (VIF) values are all less than 10 , which indicates no violation of the assumption of multi-collinearity.

Table 12: Standardized Coefficients

\begin{tabular}{|l|c|}
\hline Variables & Beta \\
\hline Participation in Decision-making & .626 \\
\hline Motivation & .532 \\
\hline Instructional Materials & .168 \\
\hline Teachers' Collaboration & .151 \\
\hline
\end{tabular}

\section{Discussion}

In this study, the researchers explored the extent to which school environmental factors such as teachers' collaboration, motivation, instructional materials, and teachers' participation in decision-making predict teachers' job satisfaction and which factor is the best predictor. This research is coming up at a time where school leaders find it difficult to retain teachers. Educational leaders need to know which factors can lead to teachers' job satisfaction because teachers leave the teaching profession due to a lack of job satisfaction. Findings from a multiple regression indicate that the model with four control variables (teachers' collaboration, motivation, instructional materials, and teachers' participation in decision making) explains $84.9 \%$ of the variance in teachers' job 
satisfaction. This implies that the school environment is critical as far as teachers' job satisfaction is concerned. It is also vital to note that teachers' participation in decisionmaking made the largest contribution (Beta= .626). This reveals that teachers' participation in decision-making is the best predictor of teachers' job satisfaction, followed by motivation (Beta $=.532$ ).

\subsection{Teachers' Collaboration and Job Satisfaction}

This study revealed that there is a moderately strong positive and statistically significant relationship between teachers' collaboration and teachers' job satisfaction. This study also found out that an increase in teachers' collaboration can greatly increase teachers' job satisfaction. This implies that the promotion of teachers 'collaboration can enhance teachers' job satisfaction. This finding support previous findings by Duyar et al. (2013) and Ronfeldt et al. (2015) that teachers' collaboration can lead to teachers' job satisfaction, commitment, and improvement in students' academic achievement. According to Herzberg's theory, interpersonal relations are very essential.

The relationship of teachers with peers, superiors, and subordinates needs to be appropriate to ensure job satisfaction. Through collaboration, teachers share ideas and help one another to overcome some of the challenges and stress that come with the increasing responsibilities. Teachers' collaboration in planning and implementing the curriculum reduces individual teachers' workload (Goddard et al., 2015; Reeves et al., 2017), consequently enhancing job satisfaction can improve students' academic performance. Moreover, collaboration allows teachers to reflect on teaching practices, leading to innovation (Vangrieken et al., 2015; Jong et al., 2019). Innovations in educational practices are helpful in the present educational system to solve complex problems affecting society. According to Urick (2016), teachers often complain that they feel isolated from colleagues and support systems, leading to dissatisfaction. If teachers work together as a team, it can reduce isolation, leading to job satisfaction (Johnson et al., 2012; Vangrieken et al., 2015).

Krammer et al. (2018) also found out that teachers working in teams enjoy shared responsibility and job satisfaction. Teachers are likely to feel comfortable in schools that promote collaboration because their social needs are met. This is in line with Maslow's hierarchy of needs theory, as Maslow clearly stated in his theory that human beings have needs and want, they wish to fulfill. The quest to satisfy the love and belonging needs can be enhanced by creating a positive environment for teachers' collaboration. Urick (2016) found out that positive relationships between teachers make them feel less frustrated. Teachers' collaboration is very vital in the modern education sector, where teachers frequently complain about stress, depression, and anxiety. Teachers who teach in schools that promote collaboration are more likely to be satisfied with the teaching profession because they feel valued and supported (Ingersoll \& Smith, 2003; Johnson et al., 2012; Forte \& Flores, 2014). There is a need for a supportive school environment to promote teachers' collaboration. Principals, as instructional leaders, need to encourage and motivate teachers to engage in collaborative activities that facilitate teaching and learning (Bahtilla \& Hui, 2020). Effective collaboration can enhance growth and 
development, leading to the job satisfaction of teachers. According to Ponjuan et al. (2011), well-planned collaborative activities can enhance the self-efficacy of teachers. This is very important because teachers' perceptions about their abilities can influence teaching practices and job satisfaction. A school environment characterized by an open climate promotes cooperation and respect among staff (Mbua, 2003; Boyd et al., 2011). This implies that the school climate and the organizational structure of a school determine teachers' collaboration. A positive school climate and a participatory organizational structure can promote teachers' collaboration.

\subsection{Participation in Decision-making and Teachers' Job Satisfaction}

In addition, this study found out that there is a strong positive and statistically significant relationship between teachers' participation in decision-making and teachers' job satisfaction. The findings also revealed that an increase in teachers' participation in decision-making would greatly increase teachers' job satisfaction. This implies that school leaders can enhance teachers' job satisfaction by involving teachers in decisionmaking. This study confirms the findings from Torres (2018) that giving teachers the chance to contribute to making school decisions can enhance teachers' job satisfaction. In line with Herzberg's theory, teachers need to be responsible for their work, and for this to happen, it means that school leaders need to give teachers the chance to make certain decisions that directly concerns them. Teachers are often left behind when it comes to decision-making. There is a need for teachers to be involved in decisions that concerns them. Teachers feel appreciated and empowered when school leaders involved them in decision-making. Teachers are leaving the teaching profession because of job dissatisfaction associated with a lack of teachers' influence over decision making (Ingersoll, 2001; Boyd et al., 2011). A supportive school environment takes teachers' feelings and opinions into consideration (Fernet et al., 2012; Jackson, 2013). According to Bahtilla (2017), most school administrators believe that if teachers are allowed to participate in decision-making, they will make decisions that favors them rather than the school's overall growth. As such, they tend to exclude teachers from participating in school decisions, making teachers feel isolated and less valued. It is necessary for school leaders to practice democratic leadership. This type of leadership empowers everyone and promotes job satisfaction. School leaders that involve teachers in decision-making are more likely to create an environment that facilitates curriculum implementation (Hallinger et al., 2017; Campbell, 2018; Baptiste, 2019). There is a need for shared leadership to give teachers' a sense of empowerment (Minarik et al., 2003). Involving teachers in decision-making makes teachers feel valued and powerful. Involving teachers in decision-making gives them a sense of belonging and, consequently, job satisfaction. Moreover, giving teachers the chance to make certain decisions concerning their classrooms can enhance their self-esteem needs.

\subsection{Motivation and Teachers' Job Satisfaction}

This study reveals that there is a moderately strong positive and statistically significant relationship between motivation and teachers' job satisfaction. Moreover, this study 
found out that an increase in teachers' motivation can significantly increase teachers' job satisfaction. This implies that school leaders can enhance job satisfaction by motivating teachers. This finding supports previous findings by Khumalo (2015) and Dou et al. (2017) that when employees are motivated, they tend to be more satisfied and committed. Motivation can increase the performance of workers (Manzoor, 2012; Ali et al., 2016). This means that motivated teachers are likely to be satisfied, leading to commitment and improving school performance. Motivation in the form of recognition and appreciation can lead to job satisfaction (Dou et al., 2017). Motivation can also be done in the form of incentives (Taniguchi \& Fujii 2016).

School leaders can motivate teachers by giving them monetary rewards or bonuses for their accomplishments. Monetary rewards can be in the form of an increase in salaries because poor salaries are one of the major reasons for what teachers, especially in developing countries, leave the teaching profession to other professions (Bahtilla, 2017). Furthermore, school leaders can use appraisal and professional development activities to motivate and retain teachers. There is a need for school leaders to identify and re-enforce teachers based on their individual needs. The alarming attrition rate is caused by teachers' dissatisfaction with their working conditions (Bahtilla, 2017). This has greatly affected students' academic performance (Ali et al., 2016). Teachers need to be motivated to equipped students with sustainable knowledge and skills. Motivated teachers are more likely to take time and plan their lessons to provide students with meaningful learning experiences to solve society's complex problems. Demotivated teachers may not be effective, which is detrimental to the education sector and society's development (Ronfeldt et al., 2013; Dupriez et al., 2016). According to Herzberg et al. (1959), factors such as recognition, achievement, responsibility, advancement, the work's meaningfulness yield positive satisfaction. This implies that the presence of these satisfiers in the school environment can make teachers feel good about their job. Teachers need to be motivated to improve the quality of education (Rooney, 2015) because motivation can improve students' academic performance; motivated teachers are likely to provide a supportive learning environment (Kaplan, 2014; Katz \& Shahar, 2015).

\subsection{Instructional Materials and Teachers' Job Satisfaction}

Furthermore, this study found out that there is a strong positive and statistically significant relationship between teachers' job satisfaction and instructional materials. The findings also revealed that an increase in instructional materials could greatly increase teachers' job satisfaction. This implies that school leaders can enhance teachers' job satisfaction by providing adequate instructional materials. This finding confirms Bakker et al. (2003) findings that resources can enhance employee motivation, leading to job satisfaction and, consequently, increased performance. According to Herzberg's theory, the work equipment should be updated and well maintained to enhance job satisfaction. Instructional materials can make teaching and learning easier, which can lead to job satisfaction. According to Olayinka (2016), instructional materials can improve students' academic achievement. This is because instructional materials help teachers explain or demonstrate a phenomenon, hence facilitating students' understanding; it is essential to 
point out that students' performance can either motivate or demotivate teachers, leading to job satisfaction or dissatisfaction. Therefore, adequate instructional materials can improve teacher effectiveness, enhance their commitment to school, and promote job satisfaction. According to Djonko-Moore (2015), high poverty schools find it difficult to provide basic facilities that can enhance learning, leading to $20 \%$ of teachers leaving high poverty schools every year. Principals, as instructional leaders, need to ensure that teachers have adequate tools and resources required for effective curriculum implementation (Alabere, 2017; Bahtilla \& Hui, 2020).

Moreover, instructional materials motivate and help students to pay attention in class. However, in most developing countries, classrooms are so bare of instructional materials, increasing the level of teacher dissatisfaction and stress (Ndongko \& Tambo 2000; Abdu-Raheem, \& Oluwagbohunmi, 2015); most often, teachers used their money to buy teaching aids. Instructional materials in most developing countries are limited to textbooks and chalkboards (Mupa \& Chinooneka, 2015), making it difficult for teachers to explain complex concepts. Inadequate instructional materials made teaching and learning stressful and tedious, which can lead to teachers' dissatisfaction. Moreover, lack of instructional materials is detrimental to the education sector because it can lead to failure to comprehend lessons. After all, teaching without instructional materials makes learning very abstract. Appropriate use of instructional materials makes learning more practical and facilitates the acquisition of sustainable knowledge and skills. Therefore, schools need to help teachers provide instructional materials to enhance students' retention and teachers' job satisfaction.

\subsection{Implications}

Firstly, this study suggests that to ensure teachers' job satisfaction, school leaders need to give teachers the freedom to make certain class decisions. Involving teachers in decisionmaking can significantly improve teachers' job satisfaction. Teachers feel powerless and undervalued when school leaders make decisions without involving them. Most teachers are dissatisfied with the teaching profession because they feel like children when school leaders give directives. Herzberg's theory points out that human beings need self-esteem, they need respect and recognition, and teachers are not an exception. School leaders can also provide teachers with opportunities for in-service training. Enhancing teachers' knowledge and skills can improve their self-efficacy and, consequently, their job satisfaction. Teachers are vital to the education sector; it is thus necessary for the education sector to be cautious when deriving motivational strategies.

Furthermore, this study suggests that there is a need for policy-makers and the education sector as a whole to take teachers' welfare as a priority; focusing only on improving students' test scores is detrimental to teachers' job satisfaction. Teachers are dissatisfied with the teaching profession because most school administrators often prioritize students' performance without paying much attention to teachers' wellbeing. Teachers are human beings with needs to be fulfilled; helping them or just showing concern may lead to job satisfaction. Herzberg's theory reveals that human beings need 
love and a feeling of belonging. Besides, policies on teachers' welfare need to be improved and ensure that they are well implemented.

In addition, this study recommends that the education sector should try as much as possible to provide teachers with adequate instructional materials needed for effective teaching and learning. Instructional materials can make teaching and learning engaging, which can lead to satisfaction. It is important to note that, as the curriculum is changing, instructional materials are also changing, which means that there is a need for school leaders to provide training on how to use modern instructional materials. In some developing countries, teachers still find it difficult to use modern instructional tools such as computers to teach effectively. With the outbreak of the COVID-19 pandemic, many schools adopted online learning, which requires modern instructional materials. To effectively carry out online studies, teachers need instructional materials more than ever before; therefore, it is necessary for school leaders to provide modern instructional materials and find specialists to train teachers to promote effective teaching and learning. If this is done, it will make teaching and learning easier, leading to job satisfaction. Besides, there is a need to pay attention to the school environment as it can either lead to teachers' job satisfaction or dissatisfaction.

Moreover, this study suggests that to ensure teachers' job satisfaction, school administrators can create socialization programs to interact and relax. This can relieve teachers from the stress and depression caused by a heavy workload and students' indiscipline. Besides, there is a need for school leaders to support teachers' associations. It is essential to point out that enhancing teachers' collaboration can create the socialization atmosphere teachers need. This is because school socialization can enhance teachers' job satisfaction, and when they are satisfied, they will likely stay in the teaching profession. Schools can also create learning communities where teachers can exchange ideas and seek help whenever needed.

\subsection{Limitations of the Study}

A limitation to this study was that only four indicators of school environment were included in the study. A lot of school environmental factors can contribute to teachers' job satisfaction. As a result of this, the researcher suggests that more school factors that can influence teachers' job satisfaction, such as students' indiscipline, school location, leadership practices, just to name be these, should be examined. Moreover, the study focuses only on teachers; there is a need to find out challenges encountered by principals in ensuring teachers' job satisfaction.

\section{Conclusion}

This study contributes to the global discussion on teachers' job satisfaction. It informed academics and society that the school environment greatly contributes to teachers' job satisfaction. It informed school leaders on what can be done to enhance teachers' job satisfaction. There is a need for school leaders to enhance teachers' collaboration, allow teachers to participate in decision making, motivate teachers and ensure that 
instructional materials are adequate. This study was also aimed at filling the gaps in literature and theory on the school environment and teachers' job satisfaction. The study's finding shows that the school environment is strongly correlated with teachers' job satisfaction, which means that more research can be carried out on other school environmental factors that can lead to teachers' job satisfaction or dissatisfaction. The researchers have also clearly explained some implications that if effectively implemented, teachers' job satisfaction will significantly improve, more experienced and qualified teachers will be retained, and consequently, students' academic performance will be improved.

\section{Funding}

This research was not funded.

\section{Informed Consent Statement}

Informed consent was obtained from all subjects involved in the study.

\section{Conflicts of Interest}

The authors declare no conflict of interest.

\section{About the Authors}

Marinette Bahtilla is a PhD-scholar in Educational Leadership and Management, Southwest University, Chongqing, China. She holds a B.Ed and M.Ed degree in Curriculum Studies and Teaching from the University of Buea. Her research interest includes; teacher education, research development, leadership and management, internationalization of higher education, supervisors' development, educational policy, curriculum development, and implementation.

Xu Hui is a professor in the Faculty of Education at Southwest University in Chongqing, China. His research interest includes; Comparative education, Assessment and Evaluation, teacher education and educational leadership and Management.

\section{References}

Abdu-Raheem, B. O., \& Oluwagbohunmi, M. F. (2015). Pre-service teachers' problems of improvisation of instructional materials in social studies Journal of Education and Practice, 6(4), 15-18

Alabere, R. A. (2017). The importance of instructional materials in teaching English as second language: International Journal of Humanities and Social Science Invention, 6(9), 36-44.

Ali, Y, S., Dahie, A. M., \& Ali, A. A. (2016). Teacher motivation and school performance, the mediating effect of job satisfaction: survey from secondary schools in Mogadishu: International Journal of Education and Social Science, 3(1) 24-38 
Alliance for Excellent Education. (2004). Teacher attrition: A costly loss to the nation and the states. Washington, DC: Alliance for Excellent Education.

Aziri, B. (2011). Job satisfaction: A literature review: Management Research and Practice, $3(4), 77$.

Bahtilla, M. (2017). The impact of working conditions on teachers' attrition in secondary schools in the Southwest Region of Cameroon: International. Journal of Education and Research, 5(6), 59-78.

Bahtilla, M., \& Hui, X. (2020). The principal as a curriculum-instructional leader: a strategy for curriculum implementation in Cameroon secondary schools. International Journal of Education and Research 8(4), 81-96.

Bakker, A. B., Demerouti, E., Taris, T. W., Schaufeli, W. B., \& Schreurs, P. J. G. (2003). A multi-group analysis of the job demands-resources model in four home care organizations International Journal of Stress Management, 10(1), 16-38

Baptiste, M. (2019). No teacher left behind: the impact of principal leadership styles on teacher job satisfaction and student success: Journal of International Education and Leadership, 9(1), 1-10

Boyd, D., Grossman, P., Ing, M., Lankford, H., Loeb, S., \& Wyckoff, J. (2011). The influence of school administrators on teacher retention decisions. American Educational Research Journal, 48(2), 303-333

Borman, G. D., \& Dowling, N. M. (2008). Teacher attrition and retention: A meta-analytic and narrative review of the research. Review of Educational Research, 78(16)367-409.

Campbell, J. W. (2018). Efficiency, incentives, and transformational leadership: Understanding collaboration preferences in the public sector: Public Performance $\mathcal{E}$ Management Review, 41(2), 277-299.

Chandra, A., Cooper, W. D., Cornick, M. F., \& Malone, C. F. (2011). A study of motivational factors for accounting educators: What are their concerns? Research in Higher Education Journal, 11(6), 19-36.

Collie, R. J., Shapka, J. D., \& Perry, N. E. (2012). School climate and social-emotional learning: Predicting teacher stress, job satisfaction, and teaching efficacy. Journal of Educational Psychology, 104, 1189-1204. http://dx.doi.org/10.1037/a0029356

Creswell, J. (2014). Qualitative, quantitative, and mixed methods approach; (4th ed.). Los Angeles, CA: Sage

Creswell, J. W. (2012). Educational Research: Planning conducting and evaluating qualitative and quantitative research. Pearson Education, Inc. Boston

Djonko-Moore, C. M. (2015). An exploration of teacher attrition and mobility in high poverty racially segregated schools. Race Ethnicity and Education, 19(5), 1063-1087.

Dou, D., Devos, G., \& Valcke, M. (2017). The relationships between school autonomy gap, principal leadership, teachers' job satisfaction, and organizational commitment. Educational Management Administration E Leadership, 4(14), 959-977.

Duyar, I., Gumus, S., \& Sukru -Bellibas, M. (2013). A multilevel analysis of teacher work attitudes: The influence of principal leadership and teacher collaboration: International Journal of Educational Management, 27(7), 700 
Dupriez, V., Delvaux, B., \& Lothaire, S. (2016). Teacher shortage and attrition: Why do they leave? British Educational Research, 42(1), 21-39

Embse, N. P., Sandilos, L. E., Pendergast, L., \& Mankin, A. (2016). Teacher stress, teaching-efficacy, and job satisfaction in response to test-based educational accountability policies. Learning and Individual Differences, 50(13), 308-317

Goddard, R., Goddard, Y., Kim, S., \& Miller, R. (2015). A theoretical and empirical analysis of the roles of instructional leadership, teacher collaboration, and collective efficacy beliefs in support of student learning. American Journal of Education, 121(4), 501-530

Fernet, C., Guay, F., Senecal, C., \& Austin, S. (2012). Predicting intraindividual changes in teacher burnout: The role of the perceived school environment and motivational factors. Teaching and Teacher Education, 28, 514-525. doi.org/10.1016/j.tate.2011.11.013.

Forte, A. M., \& Flores, M. A. (2014). Teacher collaboration and professional development in the workplace: A study of Portuguese teachers. European Journal of Teacher Education, 37(1), 91-105

Grissom, J. A., Nicholson, S. N., \& Harrington, J. A. (2014). Estimating the effects of No Child Left Behind on teachers' work environments and job attitudes. Education Policy Evaluation and analysis, 36(4), 417-436.

Gemeda, F. T., \& Tynjala, P. (2015). Exploring teachers' motivation for teaching and Professional development in Ethiopia: Voices from the field. Journal of Studies in Education, 5 (2).169-186

Hallinger, P. Walker, A. Nguyen, D, T. Truong, T., \& Nguyen, T, T. (2017). Perspectives on principal instructional leadership in Vietnam: a preliminary model. Journal of Educational Administration, 55(2), 222-239

Herzberg, F., Mausner, B., \& Snyderman, B. B. (1959). The motivation to work (2nd ed.). New York, NY: John Wiley \& Sons.

Ingersoll, R. M., \& Smith, T. (2003). The wrong solution to the teacher shortage. Educational Leadership, 60(8), 30-33.

Ingersoll, R., \& Strong, M. (2011).The impact of induction and mentoring programs for beginning teachers: A critical review of research: Review of Education Research, 81(2), 201-233.

Ikerionwu, J. C. (2000). Importance of aids and resources in classroom teaching. In A.M. Oyeneyin (Ed.), Perspective of classroom teaching. Abuja: Martmonic Investment Ltd.

Jackson, C. K. (2013). Match quality, worker productivity, and worker mobility: Direct evidence from teachers. Review of Economics and Statistics, 95(4), 1096-1116.

Johnson, S. M., Kraft, M. A., \& Papay, J. P. (2012). How context matters in high-need schools: The effects of teachers' working conditions on their professional satisfaction and their students' achievement. Teachers College Record, 114(10), 1-39.

Jong, L, Meirink J. \&., Admiraal, W. (2019). School-based teacher collaboration: Different learning opportunities across various contexts. Teaching and Teacher Education: doi.org/10.1016/j.tate.2019.102925 
Kaplan, A. (2014). Theory and research on teachers' motivation: Mapping an emerging conceptual terrain. In P. W. Richardson, S. Karabenick, \& H. M. G. Watt (Eds.), Teacher motivation: Theory and practice. New York, NY: Routledge

Katz, I, \&., Shahar, B. What makes a motivating teacher? Teachers' motivation and beliefs as predictors of their autonomy-supportive style: School Psychology International 36(6) 575-588

Krejcie, R. V., \& Morgan, D. W. (1970). Determining sample size for research activities: Educational and Psychological Measurement, 30, 608: https://doi.org/10.1177/001316447003000308

Khumalo, S. S. (2015). The implications of the System 4 approach on school leadership practices. International Education Studies, 8(7), 38-43

Krammer, M, Rossmann, P, Gastager, A \& Gasteiger-Klicpera, B. (2018). Ways of composing teaching teams and their impact on teachers' perceptions about collaboration, European Journal of Teacher Education, DOI: 10.1080/02619768.2018.1462331

Ladd, H. F. (2011). Teachers' perceptions of their working conditions: How predictive of planned and actual teacher movement? Educational Evaluation and Policy Analysis, 33(2), 235-261

Mafora, P. (2013). Managing teacher retention in a rural school district in South Africa, The Australian Association for Research in Education, 40(2), 227-240

Maslow, A. H. (1943). A theory of human motivation: Psychological Review, 50(4), 370-396.

Markos, S., \& Sridevi, M. S. (2010). Employee Engagement: The Key to Improving Performance. International Journal of Business and Management, 5(12), 89-96.

Mbua, F. N. (2003). Educational administration: Theory and practice. Limbe; Design House

McShane, S. L., \& Glinow, M. (2003). Organizational behavior: Emerging realities for the workplace revolution. Sydney: McGraw-Hill

Minarik, M. Thornton, B., \&Perreault, G. (2003). Systems thinking can improve teacher retention. The Cleaning House, 76(5), 230-234

Mupa, P., \& Chinooneka, T. I. (2015). Factors contributing to ineffective teaching and learning in primary schools: Why are schools in decadence? Journal of Education and Practice, 6(19),125-132

Manzoor, Q. A. (2012). Impact of employees' motivation on organizational effectiveness: Business Management and Strategy, 3(1), 1-12.

Ndongko, T. M ., \& Tambo, L. I. (2000). Educational development in Cameroon 1961- 1999 issues and perspectives: United State of America: Madison Wisdom Publishers Ltd.

Olayinka, A, B. (2016). Effects of instructional materials on secondary schools students' academic achievement in social studies in Ekiti State, Nigeria: World Journal of Education, 6(1) 32-39

Tillman, W. R., \& Tillman, C. J. (2008). And you thought it was the apple: A study of job satisfaction among teachers: Academy of educational leadership Journal, 12(3), 1-19.

Tatar, M., \& Horenczyk, G. (2003). Diversity-related burnout among teachers: Teaching and Teacher Education, 19, 397-408. 
Tambo, L. I. (2003). Cameroon national education policy since the 1995 Forum Limbe: Design House.

Tickle, B. R., Chang, M., \& Kim, S. (2011). Administrative support and its mediating effect on US public school teachers, Teaching and Teacher Education, 27(2), 342-349

Torres, D, G. (2018). Distributed leadership, professional collaboration, and teachers' job satisfaction in US schools. Teaching and Teacher Education, https://doi.org/10.1016/j.tate.2018.12.001

Pogodzinski, B. (2015). Administrative context and novice teacher-mentor interactions; Journal of Educational Administration, 53(8) 40-65

Ryan, R. M., \& Deci, E. L. (2000). Self-determination theory and the facilitation of intrinsic motivation, social development, and wellbeing. American Psychologist, 55, 68-78

Reeves, P, M, Pun, W., \& Chung, K, S. (2017). Influence of teacher collaboration on the job satisfaction and student achievement, Teaching and Teacher Education, doi.org/10.1016/j.tate.2017.06.016

Roby, D. E. (2012). Teacher leader human relations skills: A comparative study Journal of Education, 132 (4), 54

Rooney, E. (2015). I'm just going through the motions: High-stakes accountability and teachers' access to intrinsic rewards, American Journal of Education, 121(4), 475-500

Ronfeldt, M., Farmer, S. O., McQueen, K., \& Grissom, J. A. (2015). Teacher collaboration in instructional teams and student achievement. American Educational Research Journal, 52(3), 475-514

Ronfeldt, M., Loeb, S., \& Wyckoff, J. (2013). How teacher turnover harms student achievement. American Educational Research Journal, 50(1), 4-36

Sadri, G., \& Bowen, C. R. (2011). Meeting employee requirements: Maslow's hierarchy of needs is still a reliable guide to motivating staff. Industrial Engineer, 43(10), 44-48.

Skaalvik, E. M., \& Skaalvik, S. (2017). Still, motivated to teach? A study of school context variables, stress, and job satisfaction among teachers in senior high school. Social Psychology of Education, 20(1), 15-37

Sergent, B. (2003). Finding good teachers and keeping them; Educational Leadership, 60(8), 44 Simon, N. S., \& Johnson, S. M. (2015). Teacher turnover in high-poverty schools: What we know and can do. Teachers College Record, 117(3), 1-36

Stoeber, J., \& Rennert, D. (2008). Perfectionism in school teachers: Relations with stress appraisals, coping styles, and burnout. Anxiety, Stress, $\mathcal{E}$ Coping, 21, 37-53. http://dx.doi.org/10.1080/10615800701742461.

Urick, A. (2016). The influence of typologies of school leaders on teacher retention: Journal of Educational Administration, 54(4), 434-468

Vangrieken, K., Dochy, F., Raes, E., \& Kyndt, E. (2015). Teacher collaboration: A systematic. Review. Research Review, https://doi.org/10.1016/j.edurev.2015.04.002

Waltman, J., Bergom, I., Hollenshead, C., Miller, Jeanne, \& August, L. (2012). Factors contributing to job satisfaction and dissatisfaction among non-tenure-track faculty. The Journal of Higher Education, 83(3), 411-434. 

to copy, distribute, transmit or adapt the article content, providing a proper, prominent and unambiguous attribution to the authors in a manner that makes clear that the materials are being reused under permission of a Creative Commons License. Views, opinions and conclusions expressed in this research article are views, opinions and conclusions of the author(s). Open Access Publishing Group and European Journal of Education Studies shall not be responsible or answerable for any loss, damage or liability caused in relation to/arising out of conflicts of interest, copyright violations and inappropriate or inaccurate use of any kind content related or integrated into the research work. All the published works are meeting the Open Access Publishing requirements and can be freely accessed, shared, modified, distributed and used in educational, commercial and non-commercial purposes under a Creative Commons Attribution 4.0 International License (CC BY 4.0). 